\title{
PENGARUH CYBERBULLYINGDI MEDIA SOSIAL TERHADAP PERILAKU REAKTIF SEBAGAI PELAKU MAUPUN SEBAGAI KORBAN CYBERBULLYING PADA SISWA KRISTEN SMP NASIONAL MAKASSAR
}

\author{
Mira Marleni Pandie ${ }^{1) *}$, Ivan Th. J. Weismann ${ }^{2)}$ \\ 1) Alumni Magister Pendidikan Agama Kristen Sekolah Tinggi Theologia Jaffray \\ ${ }^{2)}$ Dosen Doktor Teologi Sekolah Tinggi Theologia Jaffray \\ *Penulis korespondensi: miramarlenipandie@gmail.com
}

\begin{abstract}
Abstrak
Penelitian ini bertujuan untuk mengetahui pengaruh cyberbullying terhadap perilaku reaktif sebagai pelaku sekaligus sebagai korban cyberbullying pada siswa. Penelitian yang digunakan adalah penelitian kuantitatif dengan menggunakan metode survei dengan mengambil sampel sebanyak 40 orang dari SMP Nasional Kota Makassar. Siswa yang dimaksud dalam penelitian ini adalah siswa SMP kelas VII sampai kelas IX karena tanggap terhadap teknologi dan pada masa ini terjadi perubahan secara fisik dan psikis yang membawa siswa pada suatu fase yang disebut masa transisi, labil, mencari identitas dan mencari public figure. Hasil dari penelitian ini adalah terbuktinya hipotesis bahwa ada pengaruh antara perilaku pelaku cyberbullying dengan perilaku reaktif siswa Kristen korban cyberbullying dengan signifikansi $0,037<0,05$. Dengan demikian jelas bahwa bila makin tinggi perilaku reaktif pelaku maka makin tinggi pula perilaku reaktif korban. Semakin rendah perilaku reaktif pelaku maka makin rendah pula perilaku reaktif korban cyberbullying.
\end{abstract}

Kata Kunci: Cyberbullying, jejaring sosial, medsos, perilaku, korban, remaja

The purpose of this research is to understand the influence of the perpetrators of cyberbullying in regards to the behavior of the victims of cyberbullying for students. The students intended in this research are Middle School students from class seven to class nine because of their technological proficiency, and at this age, they experience physical and psychological changes, that bring them to a phase known as a transition stage, label, looking for their identity, and looking for a public figure. The research that was implemented was quantitative research, using a survey method that brought in a sample of results from as many as 40 students from SMP Nasional Makassar. The researcher chose this Middle school because these middle school students demonstrated technological proficiency. The results of this research prove the hypothesis that there is an influence between the perpetrators of cyberbullying with the behavior of Christian student victims of cyberbullying as significant as $0,037<0,05$. As such, 
it is clear that the higher the reaction of the perpetrator, then the higher the reaction the behavior of the victim will be. The lower the reaction of the perpetrator, then the lower the reaction the behavior of the victim of cyberbullying.

Keywords: Cyberbullying, social network, social media, behavior, victim, teenager.

\section{Pendahuluan}

Informasi dan teknologi sekarang ini merupakan faktor yang amat dominan dalam masyarakat hampir di seluruh dunia. Memang bukan pada masa kini informasi dan teknologi penting bagi kehidupan manusia. Sejak semula informasi sudah menentukan perkembangan individu dan masyarakat. Sulit membayangkan manusia dapat mengenal diri dan sekitarnya serta memprediksi situasi yang akan dihadapi tanpa informasi. Informasi dan teknologi adalah dua hal yang tak mungkin dipisahkan. Berkat kemajuan teknologi, maka informasi menyebar secara cepat dan telah mampu mengubah bentuk kehidupan masyarakat. ${ }^{1}$

Di samping itu, era globalisasi menjanjikan kemudahan bagi manusia, terlebih pada teknologi informasi bahkan kehadiran teknologi informasi cenderung berpengaruh pada peradaban manusia. Pesatnya perkembangan teknologi informasi menyebabkan perubahan secara cepat. Sedikit demi sedikit media sosial dapat mengikutsertakan masyarakat ke dalam suatu pola budaya yang baru dan dapat menentukan pola pikir serta budaya dan perilaku dalam masyarakat. Semua bentuk perubahan dalam struktur sosial itu sangat memengaruhi pola hidup individu dalam masyarakat kontemporer ini. Melalui media elektronik dapat mengarahkan khalayak ke arah perilaku propososial ataupun antisosisal. ${ }^{2}$ Namun, dampak yang paling besar pengaruhnya pada kaum remaja karena usia ini merupakan periode transisi penuh badai dalam kehidupan batiniah anak-anak yang dapat membuat sangat labil kejiwaannya dan mudah dipengaruhi oleh rangsangan eksternal. ${ }^{3}$

Media sosial (Medsos) merupakan salah satu bentuk kemajuan teknologi informasi dan komunikasi. Melalui media sosial yang semakin banyak berkembang memungkinkan informasi menyebar dengan mudah di masyarakat. Informasi dalam bentuk apa pun dapat disebarluaskan dengan mudah dan cepat sehingga memengaruhi cara pandang, gaya hidup, serta budaya suatu bangsa. Melalui media sosial, manusia diajak berdialog, mengasah ketajaman nalar dan psikologisnya dengan alam

\footnotetext{
${ }^{1}$ Einar M. Sitompul, Gereja Menyikapi Perubahan (Jakarta: Gunung Mulia, 2006), 72.

${ }^{2}$ Kamanto Sunarto, Pengantar Sosiologi (Jakarta: Fak Ekonomi, 2012), 27.

${ }^{3}$ Kartini Kartono, Patologi Sosial 2 Kenakalan Remaja (Jakarta: PT Raja Grafindo Persada, 2013), 74.
} 
yang hanya tampak pada layar, namun sebenarnya mendeskripsikan realitas kehidupan manusia. Namun, tidak disangkal bahwa pesan-pesan yang ditayangkan melalui media elektronik dapat mengarahkan khalayak, baik ke arah perilaku prososial mau pun antisosial. ${ }^{4}$

Facebook dan Twitter menjadi pilihan mayoritas pengguna jejaring sosial, khususnya remaja sebab banyak layanan fitur yang ditawarkan dengan menarik. Sekitar 53 \% dari total pengguna facebook di Indonesia adalah remaja berusia di bawah 18 tahun. Sebuah riset yang dilakukan situs jejaring sosial Yahoo di Indonesia melaporkan bahwa pengguna terbesar internet di Indonesia adalah remaja berusia 15-19 tahun yaitu sebesar $64 \% .^{5}$ Dari laporan eMarketer yang memprediksikan jumlah pengguna jejaring sosial di masa depan, diperkirakan pada periode 20112014, Indonesia akan memiliki pengguna jejaring sosial terbesar keempat di dunia dengan jumlah mencapai 79,2 juta pada tahun 2014, meningkat dari 34,4 juta pada tahun 201l. China masih akan memimpin dengan 414,5 juta (2014), disusul AS mencapai 170,7 juta (2014), dan India dengan 129,3 juta (2014). Melihat dari angka pertumbuhannya, Indonesia menjadi negara kedua dengan pertumbuhan pengguna jejaring sosial terbesar di dunia. Nomor satu adalah India, tahun ini mencatat pertumbuhan sebesar 51,7\%, sementara Indonesia mencapai 51,6\%. China sendiri sebagai negara terbesar pengguna jejaring sosial, tahun ini hanya mencatat pertumbuhan sebesar $19,9 \%{ }^{6}$

Sekarang ini memang banyak penyedia situs berbasis sosial network. Dengan potensi jumlah pengguna yang besar di jejaring sosial, sewajarnya jika dimanfaatkan dengan bijaksana untuk mendistribusikan segala konten atau informasi dari media yang sedang dibangun. Sebab pada dasarnya jejaring sosial selain memberikan kemudahan dalam berkomunikasi dan berinteraksi dengan baik dengan lingkungan sosial, juga memberikan kesempatan kepada remaja untuk belajar sehingga tidak gagap teknologi, di samping itu dapat mempercepat maturity (kedewasaan jiwa) remaja, apabila digunakan dengan bijaksana.

Namun, tidak semua ikatan sosial bersifat mendukung. Pola jejaring sosial yang negatif dapat terjadi, sebagai contoh anggota jejaring sosial dapat terlalu kritis atau menuntut satu sama lain, atau anggota jejaring sosial dapat memperkuat atau mendorong pelaku yang membahayakan

\footnotetext{
${ }^{4}$ Kamanto Sunarto, Pengantar Sosiologi (Jakarta: Fak Ekonomi UI, 2000), 64.

5 "Banyak Remaja Indonesia jadi korban kejahatan di facebook," diakses 23 Januari 2013, http://www.hidayatullah.com/iptekes/saintek/read/2012/02/20/56844/banyakremaja-indonesia-jadi-korban-kejahatan-facebook.html.

6 "Indonesia Pengguna Jejaring Sosial," Diakses 12 September 2013, http://www.popsurvey.net/berita-dan-opini/1-news/87-terbesar-kedua-di-duniapertumbuhan-pengguna-jejaring-sosial-indonesia.
} 
atau antisosial. ${ }^{7}$ Tidak jarang komunikasi melalui jejaring sosial menuai problematika, sehingga berujung di meja hijau. Roberts mengatakan bahwa ini dikarenakan perilaku yang memang ada di dunia nyata dengan lebih mudah lagi ditranslasikan di dunia maya. ${ }^{8}$ Banyak terjadi penyalahgunaan dari situs-situs tersebut. Munculnya beberapa kasus terkait penyalahgunaan jejaring sosial marak terjadi, salah satunya adalah bullying.

Seorang anak remaja berusia 18 tahun divonis bersalah oleh pengadilan karena dianggap menghina temannya lewat jejaring sosial facebook. ${ }^{9}$ Pada tahun 2010, Nurarafa alias Farah (18 tahun) terdakwa kasus penghinaan melalui situs jejaring sosial facebook dijatuhi vonis dua bulan 15 hari dengan masa percobaan selama lima bulan oleh hakim di Pengadilan Negeri Bogor. Dalam perkara tersebut, Ferly Fandini sebagai korban melaporkan penghinaan atas dirinya yang dilakukan oleh Nurarafah alias Farah. Saat itu Farah mengaku cemburu atas kedekatan pacarnya (Ujang) dengan pelapor (korban), sehingga Farah menulis kata-kata hinaan dalam facebooknya. ${ }^{10}$

Laporan lainnya, Hannah Smith asal Inggris memilih gantung diri karena tak tahan dengan sasaran bullying di dunia maya. Hannah hanya diejek karena berat badannya. Orang-orang yang sering mengejek di dunia maya atau biasa disebut juga troll telah membuat Hannah depresi. Di antara beberapa komentar yang ditujukan untuk Hannah adalah: "Kamu jelek, mati sajalah, pasti banyak orang yang senang."ll

\section{Bullying dan Cyberbullying}

Bullying dapat didefinisikan sebagai sebuah kegiatan atau perilaku agresif yang sengaja dilakukan oleh sekelompok orang atau seorang secara berulang-ulang dan dari waktu ke waktu terhadap seorang korban yang tidak dapat mempertahankan dirinya dengan mudah atau sebuah penyalahgunaan kekuasaan/kekuatan secara sistematik. ${ }^{12}$

\footnotetext{
${ }^{7}$ Albert R. Roberts \& Gilbert J, Buku Pintar Pekerja Sosial (Jakarta: BPK Gunung Mulia, 2009), 106.

${ }^{8}$ Dominikus Juju dan Feri Sulianta, Hitam Putih Facebook (Jakarta: Elex Media Komputindo, 2010), 54.

9 "Banyak Remaja Indonesia Jadi Korban Kejahatan di facebook," Diakses 23 Januari 2013, http://www.hidayatullah .com.

${ }^{10}$ Widodo, Hukum Pidana di Bidang Teknologi Informasi Cybercrime Law, Telaah Teoritik dan Bedah Kasus (Yogyakarta: Aswaja Pressindo, 2013), 130.

11 "Empat Remaja Ini Bunuh Diri Akibat Bullying di Dunia Maya," Diakses 10 September 2013, http://www.portalkbr.com/berita/luarnegeri/2880332_4213.html.

12 Kathryn Gerald, Intervensi Praktis Bagi Remaja Be risiko (Yogyakarta: Pustaka Pelajar, 2012), 72.
} 
Kriteria pengulangan, niat dan ketidakseimbangan kekuatan sistematik menjadikan bullying bentuk agresi yang sangat tidak diharapkan. Ini dapat terjadi di banyak konteks termasuk di tempat kerja, tetapi yang paling banyak diteliti adalah di remaja. ${ }^{13}$

Cyberbullying merupakan istilah yang ditambahkan ke dalam kamus OED pada tahun 2010. Istilah ini merujuk kepada penggunaan teknologi informasi untuk menggertak orang dengan mengirim atau posting teks yang bersifat mengintimidasi atau mengancam. OED menunjukkan penggunaan pertama dari istilah ini pertama kali di Canberra pada tahun 1998, tetapi istilah ini sudah ada sebelumnya di Artikel New Yorks Time 1995 di mana banyak sarjana dan penulis Besley seorang Kanada yang meluncurkan website cyberbullying tahun 2013 dengan istilah coining. ${ }^{14}$

Pengertian cyberbullying adalah teknologi internet untuk menyakiti orang lain dengan cara sengaja dan diulang-ulang." ${ }^{15}$ Cyberbullying adalah bentuk intimidasi yang pelaku lakukan untuk melecehkan korbannya melalui perangkat teknologi. Pelaku ingin melihat seseorang terluka, ada banyak cara yang mereka lakukan untuk menyerang korban dengan pesan kejam dan gambar yang mengganggu dan disebarkan untuk mempermalukan korban bagi orang lain yang melihatnya. ${ }^{16}$

Bullying telah berkembang menjadi masalah yang saat ini dikenal sebagai cyberbullying. Tidak seperti bullying, cyberbullying memungkinkan pelaku untuk menutupi identitasnya melalui komputer. Anonimitas ini membuat lebih mudah bagi pelaku untuk menyerang korban tanpa harus melihat respons fisik korban. Pengaruh perangkat teknologi terhadap pemuda hari ini sering menyebabkan mereka untuk mengatakan dan melakukan hal-hal kejam dibandingkan dengan apa yang didapati dalam tatap muka pelaku bullying. ${ }^{17}$

\section{Cyberbullies}

Karena sifat dari komunikasi mediasi komputer, cyberbullying cocok untuk agresi relasional. Sekarang, baik pria maupun wanita dapat

\footnotetext{
${ }^{13}$ Gerald, 72.

${ }^{14}$ Sheri Bauman, Donna Cross and Jenny Walker, Principles of Cyberbullying (New York: Taylor ang Francis Group, 2013), 23.

${ }^{15}$ Arie Prabawati, Awas Internet Jahat Mengintai Anak Anda (Yogyakarta: ANDI Offset, 2013), 4; Lihat juga Martell Teasley, "Cyberbullying, Youth Behavior and Society," J Child Adolesc Behav 2 (2013):119-120, doi:10.4172/jcalb.1000119; Suniti Bhat C., "Cyber bullying: Overview and strategies for school counselors, guidance officers, and all school personnel," Australian Journal of Guidance \& Counseling 18 (2008): 53-66.

${ }^{16}$ Terry Brequet, Cyberbullying (USA: Rosyen Publishing, 2010), 37.

17 Richard Donegan, "Bullying and Cyberbullying: History, Statistics, Law, Prevention and Analysis," The Elon Journal of Undergraduate Research in Communications 3, no. l (Spring 2012): 34.
} 
melampaui batas-batas gender tradisional. Akibatnya, anak-anak lebih banyak terlibat dalam relasional agresi. Bahkan pria dan wanita mampu menggunakan strategi yang terkait, baik maskulinitas maupun feminitas. Ada penelitian yang menunjukkan bahwa perempuan lebih terlibat dalam cyberbullying dibandingkan dengan laki-laki. Adapula sebaliknya, laki-laki lebih terlibat dalam cyberbullying karena budaya maskulinitas, yang dalam teori "Male Phonemenon" percaya bahwa anak laki-laki lebih nakal daripada anak perempuan. Alasannya karena kenakalan adalah memang sifat laki-laki atau karena budaya maskulinitas menyatakan bahwa wajar kalau laki-laki nakal. ${ }^{18}$

Namun, hal itu tidak sepenuhnya benar karena baik anak laki-laki dan perempuan sama-sama berpartisipasi dalam cyberbullying, meskipun berbeda alasan. Mereka juga menggunakan metode yang berbeda. Anak perempuan cenderung lebih menggunakan pendekatan pasif, seperti menyebarkan rumor dan gosip kerusakan reputasi dan hubungan. Anak laki-laki cenderung menggunakan ancaman langsung dan cyber sebagai sarana balas dendam. Selain itu, pandangan lain mengatakan bahwa dalam menjalankan aksinya wanita lebih sering menjadi sasaran cyberbullying sedangkan laki-laki cenderung menjadi pelaku utama dalam kekerasan berkomunikasi di dunia maya.

Fakta lain mengungkapkan bahwa dalam iklim demokratisasi di segala bidang kehidupan pada era modern sekarang ini, orang cenderung mempersamakan hak-hak anak laki-laki dengan anak perempuan. Sehubungan dengan hal tersebut pada masa sekarang jumlah kejahatan yang dilakukan oleh anak perempuan tampak meningkat secara drastis. ${ }^{19}$ Berdasarkan pemikiran-pemikiran di atas, maka dapat dipastikan bahwa Cyberbullying yang dilakukan oleh remaja tidak berpatokan pada jenis kelamin, sebab seorang remaja baik laki-laki maupun perempuan dapat menjalankan aksinya sebagai Cyberbullying jika kesempatan yang dilatarbelakangi oleh motif-motif tertentu.

\section{Motif Cyberbullying}

Jika dalam bullying conventional pelaku melakukan bullying karena kurangnya perhatian, kecenderungan permusuhan, korban kekerasan merupakan motif yang mendasari tindakan cyberbullying, yakni:

\section{Dendam "The Vengeful Angel"}

Dalam iklim penuh konflik budaya ini terdapat banyak kelompok sosial yang tidak bisa didamaikan dan dirukunkan dan selalu saja

\footnotetext{
${ }^{18}$ Sarlito W. Sarwono, Psikologi Remaja (Jakarta: Rajagradindo Perkasa, 2013), 254.

${ }^{19}$ Kartini Kartono, Patologi Sosial 2, Kenakalan Remaja (Jakarta: PT Raja Grafindo Persada, 2013), 88.
} 
terlibat dalam ketegangan, persaingan dan benturan sosial yang diwarnai rasa benci dan dendam kesumat. Kebudayaan tegangan tinggi ini menjadi persemaian yang subur bagi berkembangnya tingkah laku delinkuen anak-anak, remaja dan para pemuda yang menyebarkan pengaruh jahat dan buruk dan pada akibatnya bisa mengganggu ketenteraman umum. ${ }^{20}$ Karena dendam yang tak terselesaikan pelaku melakukan aksinya dengan beberapa cara yakni:

Flaming (amarah), yaitu pendapat online menggunakan pesan elektronik dengan bahasa yang agresif atau kasar. ${ }^{21}$ Flaming mengacu kepada adanya kebencian antara dua atau lebih individual yang terjadi melalui setiap teknologi komunikasi. Biasanya flaming terjadi dalam lingkungan publik seperti chatroom atau kelompok diskusi daripada surat elektronik. Jika terjadi penghinaan berbalas-balasan, maka akan terjadi kemudian perang kata-kata yang lebih berbahaya.

Harassment (pelecehan), yakni pesan-pesan yang berisi pesan kasar, menghina atau yang tidak diinginkan, berulang kali mengirimkan pesan berbahaya untuk seseorang secara online. ${ }^{22}$ Kata-kata, perilaku atau tindakan berulang yang diarahkan pada orang tertentu atau kelompok untuk mengganggu atau menyebabkan tekanan emosional substansial dalam orang itu. Harassment merupakan pelecehan yang umumnya dipandang unik dari cyberbullying karena melibatkan pesan ofensif berulang dan pesan harassment pada umumnya dikirim melalui saluran komunikasi pribadi, termasuk email, instant messaging dan SMS.

\section{Pelaku yang Termotivasi (Motivated Offender)}

Motivasi pelaku melakukan kejahatan di internet sangatlah banyak antara lain pembajakan, balas dendam, pencurian atau sekedar iseng. Salah satu bentuk motivated offender, yakni sekedar iseng dan dalam istilah bullying bentuknya adalah: ${ }^{23}$

Denigration (pencemaran nama baik) yaitu proses mengumbar keburukan seseorang di internet dengan maksud merusak reputasi dan nama baik seseorang tersebut. Denigration merujuk kepada fitnah yang merupakan pembicaraan tentang target yang berbahaya, tidak benar, atau kejam. Sebuah sub kategori tertentu fitnah adalah posting publik atau mengirim gambar digital yang telah diubah secara digital untuk menyajikan gambar palsu, seperti menempatkan gambar seksual

${ }^{20}$ Kartini Kartono, Patologi Sosial 2, Kenakalan Remaja (Jakarta: Raja Grafindo Persada, 2013), 44.

${ }^{21}$ Nancy E. Willard, Cyberbullying and Cyberhearts (USA: Malloy, 2011), 6.

${ }^{22}$ Ibid.

${ }^{23}$ Ibid. 
eksplisit dari tubuh target yang diperoleh di tempat lain. Denigraton juga secara khusus menimbulkan masalah yang berkaitan dengan perlindungan kebebasan berbicara.

Impersonation (peniruan di mana seseorang berpura-pura menjadi orang lain dan mengirimkan pesan-pesan atau status yang tidak baik. Pelaku mengambil kesempatan dan kemampuan peniruan terhadap target dan mengirimkan materi yang mencerminkan hal buruk kepada teman target. Hal ini dapat terjadi di halaman pribadi target, web, profile, blog atau melalui bentuk komunikasi lainnya. Pertukaran password di antara pemuda atau gadis-gadis memungkinkan pelaku cyberbully untuk mendapatkan akses ke akun target dan berpose sebagai target. Setelah cyberbully berhasil menyamar jadi target, maka dengan sesuka hati mengirimkan mengirim pesan ancaman kepada guru atau siswa. Ini berdasarkan keinginan setting panggung pelaku supaya target menjadi terdakwa.

Trickery (tipu daya) yaitu membujuk seseorang dengan tipu daya supaya mendapatkan rahasia atau foto pribadi orang tersebut. Biasanya dilakukan oleh pelaku yang memang sudah kenal lama dengan korbannya, baik secara nyata maupun maya. Atau bisa juga berlanjut pada jenis cyberbully denigration dan outing, yakni dengan mencemarkan nama baik dan penyebaran foto-foto pribadi.

\section{Keinginan untuk dihormati}

Pelaku menggunakan kewenangan untuk memperlihatkan bahwa pelaku cukup kuat dalam membuat dan mengontrol orang lain dengan rasa takut. Pelaku dengan didasari keinginan untuk dihormati kadang hanya iseng untuk menyakiti remaja lain, kadang karena ketidaksukaan pelaku terhadap remaja lain. Pelaku bukanlah orang yang berpengaruh melainkan khalayak kecil di antara teman-teman atau lingkaran sekolah pelaku. Seringkali kekuasaan yang dirasakan ketika terlibat dalam cyberbullying terhadap seseorang tidak memberikan kepuasan untuk diperhatikan sebagai pribadi yang kuat dan menakutkan.

\section{Mean Girls}

Ini terjadi ketika cyberbully bosan dan mencari hiburan. Pelaku ini yang paling matang dari semua jenis cyberbullying. Biasanya dalam "Mean Girls" situasi intimidasi cyberbullies adalah perempuan. Yang paling sering pelaku lakukan adalah mengintimidasi para gadis atau anak laki-laki.

"Mean Girls" biasanya dilakukan melalui perencanaan bersama dalam kelompok dan dilakukan bersama-sama dalam suatu ruangan. Mungkin terjadi di perpustakaan, kamar tidur dan dari ruang keluarga seseorang setelah sekolah. Cyberbullies dalam "Mean Girls" hanya ingin 
terkenal dan memiliki kekuatan untuk cyberbully yang lain. Cyberbullying semacam ini tumbuh ketika adanya kekaguman dan kebanggaan kelompok. Cyberbullying jenis ini akan cepat meninggalkan tindakannya jika pelaku tidak mendapatkan nilai hiburan yang dicari. Contoh cyberbullying jenis ini adalah:

Outing, yakni menyampaikan komunikasi pribadi atau gambar yang berisi informasi yang berpotensi memalukan. Sebuah bentuk umum outing adalah ketika cyberbully yang menerima pesan surat elektronik dari target yang berisi informasi pribadi yang intim kemudian meneruskan pesan ke teman-teman yang lain. Outing dari gambar bernada seksual atau eksplisit dapat terjadi dalam konteks hubungan gagal. Ketika salah satu pihak dalam suatu hubungan berusaha untuk melepaskan diri dari hubungan tersebut, pihak lain dapat merespons dengan mendistribusikan komunikasi pribadi atau gambar yang diperoleh.

\section{The Inadvertent Cyberbully(Pelaku dengan Unsur Kesengajaan)}

Cyberbullies dengan unsur sengaja hanya merespons dan tidak pernah berpikir sama sekali akan konsekuensi dari tindakan tersebut. Para pelaku mungkin tersakiti atau marah karena komunikasi yang dikirimkan dalam berjejaring sosial. Pelaku cenderung merespon dengan marah atau frustrasi.

\section{Faktor Dasar yang Melatarbelakangi Motif Pelaku Cyberbullying}

Bullying maupun perilaku-perilaku antisosial lain yang lebih umum memiliki faktor-faktor risiko latar serupa: biologis, personal, keluarga, kelompok sebaya, sekolah/institusi dan masyarakat. Ada beberapa faktor yang memengaruhi motif perilaku cyberbullying:

\section{Prediktor Keluarga}

Khatrin mengutip pendapat Schwartz, Shields dan Cicchetti menjelaskan bahwa keterlibatan dalam membullying orang lain berkaitan dengan prediktor-prediktor keluarga, seperti kelekatan yang insecure, pendisiplinan fisik yang keras dan korban pola asuh orang tua yang overprotektif. ${ }^{24}$

Secara tidak sadar anak atau remaja memproyeksikan kekacauan batinnya keluar (disebabkan oleh berantakannya keluarga dan lingkungan rumah sendiri) dalam bentuk konflik terbuka dan perkelahian individual maupun massal. Ringkasnya kesukaan berkelahi

\footnotetext{
${ }^{24}$ Kathryn Geldard, Intervensi Praktis Bagi Remaja Be risiko (Yogyakarta: Pustaka Pelajar, 2012), 172.
} 
para remaja bisa distimulir oleh kondisi rumah tangga yang berantakan.

Perlakuan tak semestinya dan penganiayaan oleh orang tua kemungkinan besar adalah risiko-risiko faktor pada bully (pelaku bullying) atau korban atau kelompok korban agresi. Di sisi lain, situasi keluarga yang kisruh, kacau, acak-acakan, liar sewenang-wenang, main hakim sendiri, tanpa aturan dan disiplin yang baik, tidak mendidik dan tidak memunculkan iklim manusiawi maka anak secara otomatis dan tidak sadar akan mengoper adat kebiasaan tingkah laku buruk orang tua serta orang dewasa yang ada di dekatnya. Sehingga anak ikut-ikutan menjadi sewenang-wenang, liar, buas, agresif, suka menggunakan kekerasan dan perkelahian sebagai senjata penyelesaian.

\section{Faktor Internal}

Tingkah laku yang menjurus pada kriminalitas, merupakan kegagalan sistem pengontrol diri anak terhadap dorongan-dorongan instinktifnya. Dengan kata lain, anak muda tidak mampu mengendalikan naluri (instink) dan dorongan-dorongan primitifnya dan tidak bisa menyalurkannya ke dalam perbuatan yang bermanfaat dan lebih berbudaya. $^{26}$

\section{Faktor Eksternal atau Eksogen}

Faktor eksternal atau eksogen dikenal pula sebagai pengaruh alam sekitar, faktor sosial atau faktor sosiologis yang adalah semua perangsang dan pengaruh luar yang menimbulkan tingkah laku tertentu pada anak-anak remaja (tindak kekerasan, kejahatan, perkelahian massal dan seterusnya). Kelompok sebaya dan lingkungan atau iklim sekolah secara umum juga memiliki efek kuat bagi seorang siswa menjadi pelaku bullying. ${ }^{27}$

\section{Karakteristik Responden}

Jumlah responden adalah 40 orang (50\% dari populasi siswa Kristen SMP Nasional Makassar). Responden laki-laki yaitu 15 orang (37,55\%) sedangkan responden perempuan jumlahnya 25 orang $(62,5 \%)$. Berdasarkan usia responden: 12 tahun (25\%); 13 tahun (37,5\%); 14 tahun $(37,5 \%)$. Responden yang duduk di kelas 7 (25\%); kelas 8 (37,5\%); dan kelas $9(37,5 \%)$ dari keseluruhan responden dalam penelitian.

25 Kartini Kartono, Patologi Sosial 2, Kenakalan Remaja (Jakarta: RajaGrafindo Persada, 2013), 121.

${ }^{26}$ Kartini Kartono, Patologi Sosial 2, Kenakalan Remaja (Jakarta: PT Raja Grafindo Persada, 2013), 112.

${ }^{27}$ Ibid., 112. 


\section{Persentase Responden dalam Penggunaan Media Elektronik}

Persentase responden dalam penggunaan media elektronik adalah sebagai berikut.

Berdasarkan tahun pembuatan akun facebook maka diketahui bahwa sebanyak 72,5\% membuat akun pada tahun 2011; 12,5\% tahun 2012; 10\% membuat akun dibawah tahun 2010 dan 5\% mulai menggunakan facebook pada tahun 2013. Sedangkan frekuensi penggunaan facebook diketahui bahwa sebanyak 50\% menggunakan facebook sebanyak 2 jam perhari; 32,5\% menggunakan facebook 1 jam perhari; 12,5\% menggunakan facebook selama 3 jam perhari dan 5\% menggunakan facebook lebih dari 4 jam perhari.

Tempat mengakses facebook ditemukan bahwa sebanyak 80\% mengakses facebook di rumah; 10\% di sekolah; masing-masing 5\% mengakses facebook di warnet mengakses facebook di tempat lainnya. Sedangkan alat untuk mengakses facebook ditemukan sebanyak 77,5\% mengakses facebook melalui HP pribadi; 12,5\% melalui tablet berbasis android. Masing-masing 5\% melalui laptop pribadi dan komputer pribadi. Aktivitas memperbarui "status" di facebook ditemukan bahwa sebanyak 55\% memperbarui "status" di facebook 1-2 kali dalam sehari; 22,5\% memperbarui "status" 3-4 kali dalam sehari, sedangkan 20\% memperbarui statusnya 5-6 kali dalam sehari dan 2,5\% memperbarui statusnya lebih dari 7 kali sehari di facebook.

\section{Intensitas Responden sebagai Pelaku Cyberbullying}

Persentase Variabel Pelaku cyberbullying Siswa Kristen SMP Nasional Makassar ditinjau dari aspek intensitas perbuatan. Variabel pelaku Cyberbullying dalam penelitian ini diperoleh dengan membagikan kuesioner kepada 20 responden dengan 10 pernyataan. Perbandingan intensitas pelaku cyberbullying berdasarkan alternatif jawaban dapat dilihat dari diagram berikut ini.

Mayoritas responden sebesar 90\% kadang-kadang membenci teman dan melampiaskannya dengan melakukan penghinaan berbalas-balasan di facebook (Harassment). Sebanyak 85\% suka "iseng/sekadar main-main" terhadap teman dengan mengirimkan gambar-gambar dan tulisantulisan yang menyakiti teman. Sebanyak $80 \%$ diketahui sering membuat akun palsu di facebook dan dengan sesuka hati mengirimkan pesan ancaman untuk mempermalukan teman. Angka yang sama, yakni 80\% siswa Kristen kadang-kadang suka menyebarkan gosip dan rumor kepada teman melalui facebook. Di samping itu, sebanyak $75 \%$ sering memutuskan persahabatan dari daftar pertemanan di facebook terhadap teman yang menjadi saingan (exclusion) dan sebanyak 70\% dengan nama 
palsu, sering menyerang teman dengan kata-kata ancaman yang penuh bahaya agar teman menjadi takut. Terdapat angka yang sama dengan exclution, yakni sebanyak 70\% mengatakan sering membuka akun facebook teman dan mengirimkan hal-hal buruk/fitnah tanpa sepengetahuan teman (impersonation).

Selanjutnya, sebanyak 65\% sering berusaha membujuk seseorang untuk mendapatkan rahasia dan menyebarkan rahasia tersebut (Trickery). Sebanyak 60\% sering mengganggu teman dengan mengirimkan pesan teks berisi ancaman di facebook secara berulangulang/terus-menerus (Cyberstalking). Sedangkan 55\% diketahui sering mengirimkan pesan teks di facebook yang isinya merupakan kata-kata yang penuh amarah (Flaming).

Kesimpulan pada bagian ini adalah bahwa responden memiliki bentuk cyberbullying yang bervariasi dan intensitas cyberbullying yang tinggi, dengan rata-rata skor $73 \%$. Hal ini menjadi dasar bagi penulis untuk menyimpulkan bahwa cyberbullying yang dilakukan oleh siswa Kristen SMP Nasional Makassar bervariasi dan kuat.

\section{Faktor-faktor yang Mendasari Penyebab Menjadi Pelaku Cyberbullying}

Faktor penyebab pelaku cyberbullying dalam penelitian ini diperoleh dengan membagikan kuesioner kepada 20 responden dengan 30 pertanyaan yang meliputi, pertanyaan mengenai penyebab prediktor keluarga, penyebab eksogen (lingkungan) dan penyebab diri sendiri.

\section{Faktor Penyebab Prediktor Keluarga}

Hubungan antara pengaruh prediktor keluarga terhadap pelaku cyberbullying menyatakan bahwa responden memiliki tingkat pengaruh dari keluarga yang tinggi dengan skor rata-rata 70,5\%. Hal ini tentunya dapat meninggikan niat pelaku untuk melakukan cyberbullying.

\section{Faktor Penyebab Diri Sendiri}

Hubungan antara faktor internal (diri sendiri) terhadap pelaku cyberbullying menyatakan bahwa responden memiliki pengaruh pribadi yang tinggi dengan skor rata-rata 66,5\% (61-80 adalah rentang nilai tinggi/kuat).

\section{Faktor Penyebab Eksogen (Lingkungan Pergaulan)}

Hubungan antara faktor penyebab eksogen (lingkungan pergaulan) terhadap pelaku cyberbullying menyatakan bahwa responden memiliki pengaruh lingkungan yang sangat kuat yakni 82,5\% (81\%-100\% adalah 
rentang nilai tertinggi) yang sangat berpengaruh pada pelaku untuk melakukan cyberbullying.

Berdasarkan perbandingan antara faktor-faktor penyebab cyberbullying, penulis simpulkan bahwa faktor keluarga dan faktor pribadi memiliki pengaruh yang kuat bagi pelaku cyberbullying dalam menjalankan aksinya, sedangkan faktor lingkungan adalah faktor yang sangat kuat memengaruhi pelaku cyberbullying dalam tindakannya.

\section{Variabel Perilaku Korban Cyberbullying}

Variabel perilaku korban cyberbullying dalam penelitian ini diperoleh dengan membagikan kuesioner kepada 20 responden dengan 11 pernyataan. Dalam variabel ini terdiri atas sebelas indikator, yaitu takut, merasa disakiti, cemas, minder, depresi, sangat marah, frustrasi, stress, hilang kepercayaan, berkeinginan untuk bunuh diri dan membalas ancaman. Perbandingan antara besar kecilnya pengaruh pelaku cyberbullying terhadap perilaku reaktif korban cyberbullying menyatakan bahwa responden memiliki pengaruh yang tinggi atau kuat dari cyberbullying terhadap perilakunya yakni 74,5\% (61\%-80\% adalah rentang nilai tinggi/kuat).

\section{Faktor-faktor Lain Penyebab Perilaku Korban Cyberbullying}

Pengukuran mengenai faktor yang mendasari penyebab yang mendasari menjadi korban cyberbullying dilakukan dengan menanyakan mengenai perlindungan digital, faktor internal dan perlindungan sosial.

\section{Minimnya Perlindungan Sosial}

Pertanyaan mengenai minimnya perlindungan sosial sebanyak 10 butir pertanyaan. Bagaimana perbandingan antara besar pengaruh minimnya perlindungan digital, terhadap perilaku korban cyberbullying menyatakan bahwa responden memiliki pengaruh yang tinggi atau kuat dari cyberbullying terhadap perilakunya yakni $66,5 \%(61 \%-80 \%$ adalah rentang nilai tinggi/kuat).

\section{Faktor Penyebab Internal (Diri Sendiri)}

Perbandingan antara besar pengaruh internal (diri sendiri), terhadap perilaku korban cyberbullying menyatakan bahwa responden memiliki pengaruh yang tinggi atau kuat dari cyberbullying terhadap perilakunya yakni 66,07\% (61\%-80\% adalah rentang nilai tinggi/kuat).

\section{Faktor Penyebab Keluarga}

Faktor penyebab keluarga terhadap perilaku korban cyberbullying menyatakan bahwa responden memiliki pengaruh yang tinggi atau kuat 
dari cyberbullying terhadap perilakunya yakni 60,2\% (61\%-80\% adalah rentang nilai tinggi/kuat).

\section{Analisis Hubungan Antar Variabel}

Di dalam melakukan analisis, penulis menggunakan teknik analisis korelasi dengan metode korelasi person dan metode one tailed. Korelasi dengan one tailed ini digunakan karena pengujian akan lebih baik dalam menetapkan adanya korelasi, serta signifikansi yang dihasilkan jauh lebih baik. ${ }^{28}$ Uji one tailed ini juga bertujuan untuk mengetahui tingkat keeratan hubungan linear (terarah) atau normal antara dua atau lebih variabel.

\section{Korelasi Perilaku Pelaku Cyberbullying(X) dan Perilaku Korban Cyberbullying (Y)}

Pengaruh hubungan antara perilaku pelaku cyberbullying dan perilaku korban cyberbullying.

Menyatakan besarnya mean (rata-rata) dan simpangan baku (Standar Deviation) setiap variabel. Rata-rata perilaku korban cyberbullying adalah 49,45. Rata-rata pelaku cyberbullying adalah 31,55. Simpangan baku (SD) perilaku korban adalah 1,932 dan simpangan baku (SD) untuk perilaku pelaku cyberbullying adalah 3,804.

Hubungan antara perilaku pelaku cyberbullying dan perilaku korban cyberbullying mengalami kerentanan yang cukup kuat yakni 0,408 (Berdasarkan interpretasi koefisien Korelasi nilai $\mathrm{r}$ dengan interval koefisien 0,40-0,599 dengan tingkat hubungan cukup kuat).

Analisis korelasi menghasilkan nilai signifikansi antara dua variabel tersebut sebesar 0,037. Dengan nilai signifikansi 0,037, maka nilai signifikansi tersebut lebih kecil dari $\alpha \quad(0,037<0,05)$, sehingga menunjukkan bahwa variabel perilaku pelaku cyberbullying dan perilaku korban cyberbullying memiliki hubungan yang sangat signifikan. Dengan demikian $\mathrm{H}_{0}$ ditolak dan $\mathrm{H}_{1}$ diterima. Hubungan yang cukup kuat dan signifikan antara perilaku pelaku cyberbullying dan perilaku korban cyberbullying. Semakin kuat tingkat intensitas perilaku pelaku cyberbullying maka risiko pada perilaku korban juga makin tinggi.

Kesimpulan pada bagian ini adalah semakin banyak melakukan cyberbullying maka semakin meningkat perilaku korban cyberbullying. Begitu juga sebaliknya, semakin sedikit terlibat dalam tindakan cyberbullyin,g maka semakin menurun perilaku korban. Kontribusi yang

\footnotetext{
${ }^{28}$ Muhammad Nisfianoor, Pendekatan Statistika Modern Untuk Ilmu Sosial (Jakarta: Salemba Humanika, 2008), 9-10.
} 
disumbangkan perilaku pelaku cyberbullying (x) kepada perilaku korban (y) adalah 16,7\%.

Perhitungan Anova dapat dianalisis bahwa:

$\mathrm{H}_{0}$ : Model regresi linear sederhana tidak dapat digunakan untuk memprediksi pengaruh antara perilaku pelaku cyberbullying dan perilaku korban.

$\mathrm{H}_{1}$ : Model regresi linear sederhana dapat digunakan untuk memprediksi pengaruh perilaku pelaku cyberbullying terhadap perilaku korban.

Kaidah pengujiian: Berdasarkan perbandingan antara $F_{h i t u n g}$ dan $\mathrm{F}_{\text {tabel. }}$

Jika $F_{\text {hitung }} \leq \mathrm{F}_{\text {tabel }}$ maka $\mathrm{H}_{0}$ di terima

Jika $\mathrm{F}_{\text {hitung }}>\mathrm{F}_{\text {tabel }}$ maka $\mathrm{H}_{0}$ ditolak

Nilai $F_{\text {Hitung }}$ dari tabel Anova sebesar 3,605

Nilai $F$ Tabel dari tabel $F=0,999$

$F_{\text {hitung }}=3,605>F_{\text {tabel }} 0,999$ sehingga $\mathrm{H}_{0}$ ditolak

Dengan demikian regresi linear sederhana dapat digunakan untuk memprediksi perilaku korban yang dipengaruhi oleh perilaku pelaku cyberbullying. Berdasarkan perhitungan persamaan regresi untuk memperkirakan tingkat perilaku korban yang dipengaruhi oleh perilaku pelaku cyberbullying diperoleh persamaan: $y=42,904+3,9 x$. Di mana y adalah tingkat perilaku korban cyberbullying, sedangkan $\mathrm{x}$ adalah perilaku pelaku cyberbullying. Persamaan ini digunakan sebagai dasar untuk memperkirakan tingkat kenaikan korban yang dipengaruhi oleh perilaku pelaku cyberbullying akan di uji kevalidannya.

Hipotesis $\mathrm{H}_{0}$ : Tidak terdapat pengaruh antara perilaku pelaku cyberbullying dan perilaku korban cyberbullying

Hipotesis $\mathrm{H}_{1}$ : Terdapat pengaruh antara perilaku pelaku cyberbullying dengan perilaku korban cyberbullying.

Jika $\mathrm{T}_{\text {tabel }}<\mathrm{t}_{\text {hitung, }}$ maka $\mathrm{H}_{\mathrm{a}}$ diterima.

Jika $t_{\text {hitung }}>t_{\text {tabel }}$ maka $\mathrm{H}_{0}$ ditolak.

Nilai $t_{\text {hitung }}=3,9$

Nilai $t_{\text {tabel }}$ dapat dicari dengan menggunakan tabel $t_{\text {student }}$

$t_{\text {tabel }}=t(a / 2 x n-2)=t(0,05 / 2)(20-2)=t(0,205)(18)=3,6$

Membandingkan $t_{\text {tabel }}$ dan $\mathrm{t}_{\text {hitung }}$

Ternyata $t_{\text {hitung }}=3,9>t_{\text {tabel }}=3,6$, maka $\mathrm{H}_{0}$ ditolak

Keputusan: Terdapat pengaruh yang signifikan antara perilaku pelaku cyberbullying dan perilaku korban.

Berdasarkan teknik probabilitas:

$\mathrm{H}_{0}$ : Tidak terdapat pengaruh antara perilaku pelaku cyberbullying dengan perilaku korban

$\mathrm{H}_{1}$ : terdapat pengaruh antara perilaku pelaku cyberbullying dan perilaku korban 
Kriteria pengujian:

Jika: Sig $\leq$ a maka $\mathrm{H}_{0}$ ditolak

Jika: Sig > a maka $\mathrm{H}_{1}$ diterima

Nilai a karena uji satu sisi, maka nilai a $=0,05$.

Membandingkan $t_{\text {tabel }}$ dan $t_{\text {hitung, }}$

Ternyata: Sig $=0,004<0,05$, maka Ho ditolak.

Keputusan: Dengan demikian terdapat pengaruh yang signifikan antara perilaku pelaku cyberbullying dengan perilaku korban.

\section{Korelasi Antara Faktor-faktor yang Memengaruhi Perilaku Pelaku Cyberbullying}

Korelasi antara beberapa faktor yang memengaruhi perilaku pelaku cyberbullying menyatakan bahwa hubungan antara prediktor keluarga dan pelaku cyberbullying lemah, yaitu angka $(-, 115)$ yang menggambarkan hubungan negatif lemah. Korelasi tersebut menunjukkan bahwa hubungan antara prediktor keluarga dengan perilaku pelaku cyberbullying terjadi tidak searah, apabila perlindungan (keutuhan keluarga, pendidikan agama) yang didapat pada keluarga rendah (keluarga "broken," kekerasan dalam mendidik, tidak adanya pendidikan agama dan lain-lain) maka kemungkinan pelaku cyberbullying makin tinggi.

\section{Pelaku dan Faktor Diri Sendiri}

Berdasarkan hasil perhitungan data terlihat bahwa hubungan antara perilaku pelaku cyberbullying dan faktor penyebab diri sendiri yang dialami rendah yaitu angka 0,224 yang menggambarkan hubungan positif yang rendah, walaupun tidak tinggi. Korelasi positif tersebut menunjukkan bahwa hubungan antara variabel perilaku pelaku cyberbullying dengan penyebab faktor pribadi yang terjadi searah, apabila faktor pribadi pada anak yang memengaruhi tinggi (anak tidak peduli dengan hal-hal kerohanian, anak pendendam, suka mengancam, sulit menerima keberhasilan sesama, memiliki masa lalu yang buruk) maka pelaku akan reaktif.

\section{Pelaku dan Faktor lingkungan}

Berdasarkan hasil perhitungan data terlihat bahwa hubungan antara lingkungan pergaulan dan perilaku pelaku cyberbullying lemah, yaitu angka $(-, 214)$ yang menggambarkan hubungan negatif kuat. Korelasi tersebut menunjukkan bahwa hubungan antara lingkungan dengan perilaku pelaku cyberbullying terjadi tidak searah, apabila perlindungan yang didapatkan pada lingkungan pergaulan rendah (Bersahabat dengan teman yang berbicara dan berperilaku kasar, bersahabat dengan teman 
yang suka menghina, fitnah, minim prestasi, negative thinking, membuat kelompok-kelompok "grup") maka reaktif cyberbullying makin tinggi.

\section{Korelasi Antara Faktor yang Memengaruhi Perilaku Korban Cyberbullying}

Berikut akan dipaparkan korelasi antara beberapa faktor yang memengaruhi perilaku pelaku cyberbullying.

\section{Perilaku Korban Cyberbullying dan Minimnya Perlindungan Digital}

Hubungan antara perilaku pelaku cyberbullying dan faktor penyebab diri sendiri yang dialami rendah yaitu angka 0,27l yang menggambarkan hubungan positif yang rendah, walaupun tidak tinggi. Korelasi positif tersebut menunjukkan bahwa hubungan antara variabel perilaku korban cyberbullying dengan penyebab faktor minimnya perlindungan digital yang terjadi searah (Mengabaikan pengaturan privasi, suka membuat user name yang menarik, kebiasaan lupa log out, memasang foto seksi, membuka pesan tak terindetifikasi, memberikan password pada teman, tidak sopan dalam komunikasi dalam dunia maya, malas "google" diri), dalam hal ini, apabila faktor minimnya perlindungan digital yang memengaruhi tinggi maka, tingkat perilaku korban cyberbullying akan semakin tinggi.

\section{Perilaku Korban Cyberbullying dan Minimnya Perlindungan Diri}

Hubungan antara perilaku korban cyberbullying dan faktor penyebab diri sendiri yang dialami rendah yaitu angka 0, 368 yang menggambarkan hubungan positif yang rendah, walaupun tidak tinggi. Korelasi positif tersebut menunjukkan bahwa hubungan antara variabel perilaku korban cyberbullying dengan penyebab faktor pribadi yang terjadi searah, apabila faktor minimnya perlindungan pribadi yang memengaruhi tinggi (Tidak peduli dengan kegiatan kerohanian, tidak suka dikritik, tidak teliti, sering merasa tersaingi, tidak percaya diri, sulit atasi kegagalan, mudah "down" cepat bereaksi, suka menyendiri, bergaul dengan orang-orang yang bisa menyenangkan, hidup dalam kekecewaan, suka menggosip/fitnah) maka kerentanan menjadi korban akan semakin tinggi.

\section{Perilaku korban dan Faktor Perlindungan Sosial (Keluarga)}

Berdasarkan hasil perhitungan data terlihat bahwa hubungan antara pelaku korban cyberbullying dan faktor penyebab diri sendiri yang dialami rendah yaitu angka $(-0,062)$ yang menggambarkan hubungan negatif. Korelasi negatif tersebut menunjukkan bahwa hubungan antara variabel perilaku korban cyberbullying dengan penyebab faktor perlindungan sosial 
yang terjadi tidak searah, apabila faktor perlindungan sosial keluarga yang terjadi pada siswa semakin rendah (Komunikasi buruk dengan orang tua, orang tua suka membanding-bandingkan, orang tua mentelantarkan, orang tua tidak peduli dengan kegiatan kerohanian), maka perilaku korban akan semakin tinggi.

\section{Diskusi}

Dengan kemajuan teknologi maka memungkinkan manusia mampu berkomunikasi dengan orang-orang di belahan dunia lain tanpa harus bertatap muka secara langsung, misalnya yang ada sekarang dan lagi trend adalah facebook. Akhir-akhir ini facebook telah menjadi wadah untuk membina pertemanan dan hubungan sosial. Penggunaan facebook ini telah menjadi hal yang wajar. Namun, jika penggunaan situs jejaring sosial (Facebook) ini tidak diringi oleh perlindungan digital, perlindungan sosial/keluarga serta perlindungan pribadi sendiri, tentunya akan menempatkan pengguna tersebut dalam keadaan yang riskan.

Ada beberapa temuan khas dari penelitian ini yang dapat didiskusikan lebih lanjut:

Kondisi temuan data yang memiliki korelasi yang rendah walaupun signifikan, menandakan bahwa ada beberapa indikator yang lemah dan harus diperbaiki jika diadakan penelitian lanjutan mengenai tema dalam penelitian ini

Pertama, peran keluarga dan diri sendiri serta perlindungan digital untuk mencegah siswa dari cyberbullying dinilai kurang maksimal untuk melindungi korban.

Kedua, terlalu dininya usia anak-anak pengguna jaringan sosial facebook menyebabkan anak belum memahami etika berkomunikasi di dunia maya dan aturan hukum yang menyertainya.

Oleh sebab itu, pentingnya lembaga lain khususnya untuk memberikan regulasi dalam upaya melindungi anak yang beraktifitas di dunia maya. Selain itu peran orang tua, lembaga pendidikan serta pendidikan Kristen diharapkan aktif dalam memberikan solusi dan pandangan yang menolong siswa agar selalu terlindungi dari pengaruh buruk dunia cyber.

\section{Kesimpulan}

Jejaring sosial sebagai wadah komunikasi dunia maya dapat menghubungkan komunikasi antar sesama bahkan antar negara. Komunikasi di dunia maya (cyber), secara khusus facebook memiliki dampak positif dan negatif. Memang, jika dimanfaatkan dengan benar, komukasi melalui facebook dapat memberikan manfaat bagi 
penggunanya. Namun, jika komunikasi yang digunakan di facebook tidak berdasarkan pada etika komunikasi secara khusus komunikasi Kristen, maka dampaknya adalah penyalahgunaan facebook yang berujung pada munculnya perilaku-perilaku korban komunikasi berjejaring.

Hasil penelitian menunjukkan bahwa hipotesis dalam penelitian ini dapat dibuktikan. Analisa hasil uji korelasi menyebutkan bahwa ada hubungan positif dan signifikan antara perilaku pelaku cyberbullying dan perilaku korban cyberbullying dengan nilai signifikansi 0,037<0,05, yang mana semakin reaktif perilaku pelaku cberbullying maka semakin semakin reaktif pula perilaku korban cyberbullying.

Analisis terhadap faktor-faktor yang menyebabkan perilaku pelaku cyberbullying dalam melakukan aksinya, yakni faktor keluarga, faktor diri sendiri dan lingkungan juga memiliki tingkat pengaruh yang kuat dan signifikan. Analisis terhadap terhadap pengaruh antara perlindungan digital, perlindungan sosial dan faktor diri sendiri juga berpengaruh pada perilaku korban. Pelayanan yang bisa dilakukan oleh gereja seperti "support group" untuk anak-anak yang menjadi korban cyberbullying. Regulasi pemerintah untuk memberikan sanksi dan denda yang bisa diberikan kepada pelaku cyberbullying. Mungkin harus ada seminar dan publikasi bagi orang tua supaya mereka mengetahui bagaimana menghadapi masalah cyberbullying ini.

\section{Kepustakaan}

Bauman, Sheri, Donna Cross and Jenny Walker, Principles of Cyberbullying. New York: Taylor Ang Francis Group, 2013.

"Banyak Remaja Indonesia jadi korban kejahatan di facebook." Diakses 23 Januari 2013. http://www.hidayatullah.com/iptekes/saintek/read/ 2012/02/20/56844/banyak-remaja-indonesia-jadi-korban-kejahatanfacebook.html.

Brequet, Terry. Cyberbullying. USA: Rosyen Publishing, 2010.

C., Suniti Bhat. "Cyber bullying: Overview and strategies for school counselors, guidance officers, and all school personnel." Australian Journal of Guidance \& Counseling 18 (2008): 53-66.

Donegan, Richard. "Bullying and Cyberbullying: History, Statistics, Law, Prevention and Analysis," The Elon Journal of Undergraduate Research in Communications 3, no. 1 (Spring 2012):33-42.

"Empat Remaja Ini Bunuh Diri Akibat Bullying di Dunia Maya." diakses 10 September 2013. http://www.portalkbr.com/berita/luarnegeri/2880332_4213.html.

Gerald, Kathryn. Intervensi Praktis Bagi Remaja Be risiko. Yogyakarta: Pustaka Pelajar, 2012. 
"Indonesia Pengguna Jejaring Sosial." Diakses 12 September 2013, http://www.popsurvey.net/berita-dan-opini/l-news/87-terbesarkedua-di-dunia-pertumbuhan-pengguna-jejaring-sosial-indonesia.

Juju, Dominikus dan Feri Sulianta, Hitam Putih Facebook. Jakarta: Elex Media Komputindo, 2010.

Kartono, Kartini. Patologi Sosial 2 Kenakalan Remaja. Jakarta: PT Raja Grafindo Persada, 2013.

Nisfianoor, Muhammad. Pendekatan Statistika Modern Untuk Ilmu Sosial. Jakarta: Salemba Humanika, 2008.

Prabawati, Arie. Awas Internet Jahat Mengintai Anak Anda. Yogyakarta: ANDI Offset, 2013.

Roberts, Albert R. \& Gilbert J, Buku Pintar Pekerja Sosial. Jakarta: BPK Gunung Mulia, 2009.

Sarwono, Sarlito W. Psikologi Remaja. Jakarta: Rajagradindo Perkasa, 2013.

Sitompul, Einar M. Gereja Menyikapi Perubahan. Jakarta: Gunung Mulia, 2006.

Sunarto, Kamanto. Pengantar Sosiologi. Jakarta: Fakultas Ekonomi, 2012.

Teasley, M. "Cyberbullying, Youth Behavior and Society," J Child Adolesc Behav 2 (2013):119-120. doi:10.4172/jcalb.1000119.

Widodo, Hukum Pidana di Bidang Teknologi Informasi Cybercrime Law, Telaah Teoritik dan Bedah Kasus. Yogyakarta: Aswaja Pressindo, 2013.

Willard, Nancy E. Cyberbullying and Cyberhearts. USA: Malloy, 2011. 